\title{
PENGEMBANGAN KARAKTER DALAM OLAHRAGA DAN PENDIDIKAN JASMANI
}

\author{
Sri Winarni \\ FIK Universitas Negeri Yogyakarta (e-mail: winuny@yahoo.co.id; HP: 08121570201)
}

\begin{abstract}
Character Development in Sports and Physical Education. There are three approaches to character development, i.e. the social learning, structural development, and socio-psychological approaches. These underlie nine strategies to develop character through physical and sports activities. The strategies can be implemented by formulating characteristics of real sportspeople in a program, strengthening sportsmanlike behaviors, modeling good and appropriate behaviors, explaining why particular behaviors are good and acceptable, discussing moral dilemmas, actualize moral dilemmas in actual situations, teaching cooperative learning strategies, creating an atmosphere that motivates movement tasks, and transferring power from leaders to participants (members).
\end{abstract}

Keywords: character development, sports, physical education

\section{PENDAHULUAN}

Selama proses belajar mengajar pendidikan jasmani, ketika permainan sepak bola menjadi pilihan materi pembelajaran, dan seorang siswa men-tackle siswa lain secara agresif sehingga menyebabkan cedera pada pemain yang bersangkutan. Contoh lain ketika sedang bermain bola voli, banyak para siswa merasa gagal dan tidak mampu bermain sehingga menyebabkan siswa mengalami kejenuhan dan malas belajar pendidikan jasmani dan olahraga. Pada saat bermain bola basket, seorang pemain bertindak bermain sendiri dan tidak mau bermain secara kelompok sehingga yang bersangkutan merasa paling hebat. Semua ini adalah masalahmasalah moral, yang lebih jauh menjadi masalah karakter.
Dalam sebuah pertandingan, seorang pemain bola mengetahui bahwa berbuat mencederai lawan adalah perbuatan tidak fair. Pemain tersebut tidak mau mencederai lawannya tetapi karena desakan pelatih, akhirnya melakukannya. Dua orang bermain tenis tanpa ada wasit. Seorang pemain, sebut saja Badu, ingin memenangkan pertandingan saat itu karena beberapa kali selalu tidak beruntung. Dia memerlukan angka untuk dapat memenangkan pertandingan. Pada akhir suatu bola rally, setelah tidak dapat mengembalikan bola, Badu mengetahui bahwa bola jatuh di dalam daerah permainannya sendiri. Karena Badu telah memutuskan untuk memenangkan pertandingan saat itu, dan sangat ingin memenangkan pertandingan itu, dia menyatakan bahwa bola yang tidak terjangkaunya tadi jatuh di luar 
area permainan sendiri, meskipun dia tahu bahwa perbuatan seperti itu tidak fair, tetapi dia akhirnya berbuat tidak jujur juga.

Sebagai seorang guru pendidikan jasmani, seberapa peduli seorang guru pendidikan jasmani terhadap isu-isu seperti ini? Seorang guru pendidikan jasmani tidak hanya mengajar aspek fisikal siswa saja, tetapi juga aspek sosial dan moral. Guru pendidikan jasmani dapat melakukan hal ini baik secara sadar maupun tidak sadar. Jika seorang guru pendidikan jasmani merasa tidak setuju dengan satu sikap dan perilaku siswa, maka guru tersebut harus dapat membuat suasana pemebelajaran yang mengoreksi sikap dan perilaku tersebut.

Bagaimana pendidikan jasmani dapat mengajarkan karakter-karakter moral yang diinginkan? Bagaimana pula guru pendidikan jasmani mengembangkan sikap dan perilaku moral siswa? Sementara dibalik ini semua, diyakini bahwa pendidikan jasmani dapat mengembangkan aspek-aspek sosial dan moral para siswa. Hal ini dapat terjadi ketika pendidikan jasmani dan olahraga membangun karakter dan nilai-nilai yang bermoral. Seperti halnya diyakini bahwa olahraga dapat mengembangkan sikap fair play dan sportmanship bagi setiap pelakunya.

Perkembangan etika-sosial siswa dapat menjadi salah satu tujuan penyelenggaraan pendidikan jasmani di berbagai negara. Namun, beberapa studi menunjukkan bahwa pendidikan jasmani tidak memiliki bukti-bukti ini. Sebagai contoh, kontribusi positif pendidikan jasmani dari beberapa literatur diyakini hanya merupakan mitos-tua dan tidak dilandaskan pada penelitianpenelitian empiris (pentingnya olahraga bagi masyarakat, kesehatan, sosialisasi, dan ekonomi). Sebaliknya, menurut Shields \& Bredemeier (Auweele, 1999) 322), beberapa hasil penelitian menyebutkan bahwa pendidikan jasmani jika dilaksanakan dalam pengendalian yang seksama akan dapat mempromosikan perilaku-perilaku positif sosial dan pikiran-pikiran moral.

Beberapa hasil penelitian masih menunjukkan konflik tentang efek-efek sosial pendidikan jasmani, yang nampaknya belum bisa menunjukkan efek yang jelas dan tegas. Hasil penelitian lain menyebutkan bahwa hal terpenting yang dapat mempengaruhi terbentuknya keterampilan sosial dan perilaku moral positif siswa bisa terjadi manakala pendidikan jasmani diorganisasir secara sosial dan bergantung pada metode pengajaran yang digunakan guru. Melalui tulisan ini, penulis ingin menunjukkan bahwa pendidikan jasmani dapat menjadi lingkungan yang baik untuk perkembangan moral siswa asalkan mempertimbangkan beberapa syarat yang diperlukan. Isu penting lain adalah bahwa pendidikan jasmani mengembangkan hubungan erat antara perilaku sosial dengan pikiran moral. Hal ini sangat terkait dengan terjadinya peristiwa interaksi sosial diantara para siswa ketika sedang belajar pendidikan jasmani dan olahraga.

\section{NILAI-NILAI KARAKTER DALAM OLAHRAGA}

Menurut Hodge (Gould, 2003:533), kebanyakan orang sepertinya meyakini bahwa berpartisipasi dalam program 
aktivitas jasmani mengembangkan karakter secara otomatis, meningkatkan alasan-moral, dan mengajarkan nilai dari ciri-ciri olahragawan sejati, tetapi sedikit bukti bahwa itu semua membangun karakter. Partisipasi dalam pendidikan jasmani dan olahraga tidak secara otomatis menghasilkan orang yang baik atau jahat. Karakter tidak datang dengan sendirinya, tetapi diajarkan dalam program pendidikan jasmani dan olahraga, pengajaran alasan-moral dan nilai-nilai olahraga itu melibatkan penggunaan strategi tertentu yang sistematis.

Bagaimana kaitan antara karakter dan olahraga? Telah menjadi keyakinan umum bahwa aktivitas olahraga syarat dengan nilai-nilai karakter seperti kejujuran, sportivitas, disiplin, dan kepemimpinan. Weinberg dan Gould (2003: 527) mengatakan bahwa karakter merupakan sebuah konsep dari moral, yang tersusun dari sejumlah karakteristik yang dapat dibentuk melalui aktivitas olahraga, antara lain: rasa terharu (compassion), keadilan (fairness), sikap sportif (sport-personship), integritas (integrity).Semua nilai-nilai tersebut ditanamkan melalui ketaatan atau kepatuhan seseorang dalam berkompetisi sesuai dengan peraturan permainan yang berlaku pada cabang olahraga yang digelutinya. Di dalam peraturan permainan melekat semangat keadilan dan tuntutan kejujuran para pelaku olahraga saat menjalankan pertandingan.

Terdapat ungkapan yang sudah menjadi keyakinan sejarah dari waktu ke waktu: Sport build character (Maksum, 2005; 2002). Kofi Anan, mantan Sekjen PBB pernah menyatakan: Sport teaches life skill - sport remains the best school of life (United Nation, 2003). United Nations melalui Task force on Sport for Development and Peace menyatakan bahwa olahraga merupakan instrumen yang efektif untuk mendidik kaum muda, terutama dalam halnilai-nilai (lihat Tabel 1). Sejak tahun 2000, United Nations mengembangkan program yang disebut Young Education through Sport, sebuah model program olahraga dan pendidikan bagi kaum muda. Sebagai pilot project, program ini telah dilakukan di Zimbabwe, mencakup 10 propinsi dengan 25 ribu partisipan (United Nations, 2003).

\section{BEBERAPA BUKTIOLAHRAGA DAN PENDIDIKAN JASMANI MEMBA- NGUN KARAKTER \\ Olahraga Remaja sebagai Pencuci Peri- laku Negatif}

Bukan hanya guru pendidikan jasmani yang menyatakan bahwa berpartisipasi dalam aktivitas jasmani meningkatkan perkembangan karakter dan perilaku positif. Administratur olahraga, para pelatih, dan tokoh olahraga di masyarakat juga sering mengklaim bahwa berpartisipasi dalam kegiatan olahraga bagi kaum generasi muda mencegah kenakalan di jalanan, jauh dari masalah sosial, dan terhidar dari perilaku gang (seperti: gang motor). Eric Larson (Gould, 2003:533), seorang ahli di bidang perkembangan remaja, memberikan contoh, kegiatan ekstrakurikuler olahraga sangat potensial untuk mengarahkan anak memiliki perilaku positif, dengan beberapa alasan. Pertama, olahraga secara intrinsikmemotivasi remaja. Kedua, melibatkan upaya yang terus-menerus untuk berpartisipasi ke arah tujuan 
yang diinginkan. Ketiga, olahraga membutuhkan seperangkat pengalaman, membuat penyesuaian, dan belajar untuk mengatasi masalah. Sejalan dengan hal itu, Martinek \& Schilling (2009) menggagas sebuah program yang disebut sebagai After Shool Program. Program ini dilandasi pemikiran Halpern (2005) sebagai upaya memenuhi kebutuhan perkembangan anak, ketika anak secara alamiah memerlukan kegiatan-kegiatan yang berdampak positif bagi perkembangan aspek moral, dan mencari serta medapatkan pengalamanpengalaman ke arah kebiasaan atau kegiatan positif. Anak-anak memerlukan ruangan untuk mengekspresikan kompetensinya secara spontan melalui berbagai ekspresi dan eksplorasi kegiatan jasmani. Selain itu, anak-anak juga memerlukan tempat yang nyaman untuk mewujudkan apa yang sebenarnya dimiliki dan diinginkan.

Tabel 1: Beberapa Indikator Nilai dalam Praktek Olahraga dan Kehidupan

\begin{tabular}{|c|c|c|}
\hline Nilai Moral & Praktek dalam Olahraga & Praktek dalam Kehidupan \\
\hline Respek & $\begin{array}{l}\text { - Hormat pada aturan main dan tradisi. } \\
\text { - Hormat pada lawan dan offisial. } \\
\text { - Hormat pada kemenangan dan } \\
\text { kekalahan. }\end{array}$ & $\begin{array}{l}\text { - Hormat pada orang lain } \\
\text { - Hormat pada hak milik orang } \\
\text { lain } \\
\text { - Hormat pada lingkungan dan } \\
\text { dirinya }\end{array}$ \\
\hline $\begin{array}{l}\text { Tanggung } \\
\text { jawab }\end{array}$ & $\begin{array}{l}\text { - Kesiapan diri melakukan sesuatu. } \\
\text { - Disiplin dalam latihan dan bertanding. } \\
\text { - Kooperatif dengan sesama pemain. }\end{array}$ & $\begin{array}{l}\text { - Memenuhi kewajiban } \\
\text { - Dapat dipercaya } \\
\text { - Pengendalian diri }\end{array}$ \\
\hline Peduli & $\begin{array}{l}\text { - Membantu teman agar bermain baik } \\
\text { - Membantu teman yang bermasalah } \\
\text { - Murah pujian, kikir kritik } \\
\text { - Bermain untuk tim, bukan diri sendiri }\end{array}$ & $\begin{array}{l}\text { - Menaruh empati } \\
\text { - Pemaaf } \\
\text { - Mendahulukan kepentingan } \\
\text { yang lebih besar }\end{array}$ \\
\hline Jujur & $\begin{array}{l}\text { - Patuh pada aturan main } \\
\text { - Loyal pada tim } \\
\text { - Mengakui kesalahan }\end{array}$ & $\begin{array}{l}\text { - Memiliki integritas } \\
\text { - Terpercaya } \\
\text { - Melakukan sesuatu dengan baik }\end{array}$ \\
\hline Fair & $\begin{array}{l}\text { - Adil pada semua pemain termasuk } \\
\text { yang berbeda } \\
\text { - Memberikan kesempatan kepada } \\
\text { pemain lain }\end{array}$ & $\begin{array}{l}\text { - Mengikuti aturan } \\
\text { - Toleran pada orang lain } \\
\text { - Kesediaan berbagi } \\
\text { - Tidak mengambil keuntungan } \\
\text { dari kesulitan orang lain }\end{array}$ \\
\hline Beradap & $\begin{array}{l}\text { - Menjadi contoh/model } \\
\text { - Mendorong perilaku baik } \\
\text { - Berusaha meraih keunggulan }\end{array}$ & $\begin{array}{l}\text { - Mematuhi hukum dan aturan } \\
\text { - Terdidik } \\
\text { - Bermanfaat bagi orang lain } \\
\end{array}$ \\
\hline
\end{tabular}

Potensi olahraga sebagai media positif bagi perkembangan remaja telah banyak ditelaah oleh para ahli psikilogi dan sosiologi. Untuk dapat menjawab dua pertanyaan, apakah berpartisipasi dalam kegiatan olahraga mencegah kejahatan ringan/penyimpangan sosial? Apakah berpartisipasi dalam olahraga juga mampu menekan perilaku kekerasan gang (seperti: gang motor)? 


\section{Pengaruh Positif Olahraga}

Menurut Seefeldt \& Ewing, Shields \& Bredemeier, (Gould, 2003:534), penelitian telah menunjukkan bahwa partisipasi remaja dalam kegiatan olahraga mengurangi perilaku kejahatan daripada para remaja yang tidak berpartisipasi dalam kegiatan olahraga. Lebih lanjut dinyatakan, hubungan negatif antara partisipasiberolahraga dengan kejahatan ringan/penyimpangan sosial tampak lebih menguat pada remaja yang berada dalam komunitas miskin. Namun demikian, hal yang belum nampak jelas adalah mengapa hubungan ini bisa muncul? Untuk keperluan itu, beberapa hal yang perlu mendapat penjelasan adalah kesenjangan sosial, ikatan sosial, pelabelan sosial, dan pembedaan ekonomi.

Hubungan negatif antara berpartisipasi dalam kegiatan olahraga dengan penyimpangan sosial berupa kesenjangan sosial, ketika para atlet tidak sering, dan tidak intens berinteraksi dengan penyimpangan sosial. Dengan perkataan lain, berpartisipasi dalam kegiatan olahraga menjaga remaja jauh dari kegiatan di jalanan dan jauh dari masalahmasalah sosial.

Ikatan sosial dicirikan oleh remaja yang berpartisipasidalam kegiatan olahraga mengembangkan rasa pengakuan terhadap orang lain, terutama pada orang yang dominan, pro nilai-nilai sosial. Seorang atlet muda mengidentifikasi dirinya dengan pelatihnya dan regunya dan karena itu mereka belajar nilai-nilai kerjasama, kerja keras, dan berprestasi.

Pelabelan sosial dicirikan oleh tumbuh kembangnya pengakuan nilai-nilai sosial seiring dengan makin meningkatnya partisipasi remaja dalam kegiatan sosial. Para atlet remaja sering mendapatkan pengakuan sosial, sehingga pada saat yang bersamaan menumbuhkan kebanggaan sosial. Karena itu, berpartisipasidalam kegiatan olahraga bagi kalangan remaja menumbuhkan pengakuan sosial, yang pada gilirannya akan mencirikan label nama sosial dan nilainilai sosial yang ada dalam struktur masyarakat.

Pembedaan ekonomi yang dimaksud dicirikan oleh banyaknya atlet yang berasal dari kalangan status ekonomi rendah-menengah yang ingin memperbaiki tingkat ekonomi kehidupannya dengan berpartisipasi dalam kegiatan olahraga untuk kenikmatan dan perbaikan status ekonomi. Berpartisipasi dalam kegiatan olahraga bagi kalangan remaja untuk meningkatkan prestise dan status, sehingga pada gilirannya akan mengurangi jurang pembedaan ekonomi, dan mengantarkan atlet hidup lebih baik, serta memberikan keyakinan untuk dapat meraih tujuan yang diinginkannya.

Meskipun penjelasan ini dapat membantu memberikan pemahaman yang lebih baik mengapa berpartisipasi dalam kegiatan olahraga dapat menekan penyimpangan sosial, namun tidak seutuhnya memberikan kesimpulan yang jelas. Tetapi, paling tidak hubungan berpartisipasi dalam kegiatan olahraga dengan penyimpangan sosial dapat dijelaskan oleh pandangan-pandangan seperti di atas, meski dalam beberapa hal diperlukan penelitian lebih lanjut. 
Partisipasi Berolahraga dan Perilaku (Kelompok) "Gang"

Gang dan perilaku negatif berkaitan satusama lain (misalnya: kejahatan, perkelahian, atau pembunuhan). Di kotakota besar dan daerah urban serta berbagaidaerah kontemporer perilaku gang ini sering muncul. Berpartisipasi dalam olahraga diarahkan sebagai suatu alternatif untuk menekan perilaku gang dalam beberapa alasan. Pertama, beberapa alasan mengapa remaja membentuk gang adalah sebagai bentuk kelompok "aliansi" tandingan keluarga, rendahnya self esteem, dan rendahnya model peran positif. Kedua, anak-anak remaja terpelihara menjadi anggota gang ka-rena merasa terpenuhi segala kebutuhannya dalam berbagai cara. Seakan-akan, gang memberikan identitas dan pengakuan sebagaimana fungsinya dalam sebuah keluarga.

Namun demikian, telah banyak disarankan, bahwa berpartisipasi dalam kegiatan olahraga dapat berfungsi sebagai pengganti layanan yang diberikan dalam sebuah gang. Terutama, ketika anak-anak remaja berpartisipasi dalam kegiatan olahraga (karena lemahnya pengawasan orang tua, atau karena tekanan ekonomi), maka perlu difasilitasi untukmengembangkan selfesteem, memberikan rasa identitas penting, memberikan dukungan sosial, dan memberikan peran model positif. Dengan demikian, telah sering terbukti bahwa berpartisipasi dalam kegiatan olahraga adalah alternatif untuk menekan terbentuknya gang di kalangan generasi muda.

Penting untukdipahamibahwa olahraga akan memberikan suatu alternatif terhadap perilaku negatif ketika program olahraga itu dijalankan secara tepat, terorganisir, dan sungguh-sungguh diimplementasikan. Olahraga tidak akan menguntungkan dengan sendirinya, tetapi perlu dikelola dan diarahkan agar memberikan keuntungan fisiologis dan psikologis, seperti sering dikemukakan dalam berbagai literatur sosiologi atau psikologi olahraga. Pembentukan nilai dilihat sebagai sebuah proses reorganisasi dan transformasi struktur dasar penalaran individu(Maksum, 2007; Shields, \& Bredemeier, 2006). Pembentukan nilai bukanlah sekadar menemukan berbagai macam peraturan dan sifat-sifat baik, melainkan suatu proses yang membutuhkan perubahan struktur kognitif dan rangsangan dari lingkungan sosial. Dengan demikian, berpartisipasi dalam kegiatan olahraga tidak dengan sendirinya membentuk nilai individu, tetapi apa yang dianggap sebagai nilai-nilai nilai tersebut harus diorganisasi, dikonstruksi, dan ditransformasikan ke dalam struktur dasar penalaran individu yang berpartisipasi di dalamnya (Stornes \& Ommundsen, 2004; Stuntz \& Weiss, 2003).

Suatu penelitian yang dilakukan oleh (Trulson, 1986; dalam Gould, 2003: 535), yang membagi kelompok remaja nakal kedalam tiga kelompok berbeda. Kelompok pertama, melakukan olahraga Tae Kwon Dodengan menekankan pada pertarungan dan teknik mempertahankan diri. Kelompok kedua, melakukan olahraga Tae Kwon Do secara tradisional, yang menekankan pada refleksi filosopikal, meditasi, dan latihan jasmani. Kelompok ketiga, sebagai ke-lompok kontrol mendapatkan perlakuan bermain 
sepakbola dan basket. Setelah selama enambulan, remaja pada kelompok pertama kurang baik dalam penyesuaian danmendapat skor tertinggi pada pengukuran agresi dan penyimpangan sosial daripada skor yang sama pada awal perlakuan. Remaja pada kelompok kedua, menunjukkan sikap agresi di bawah normal dan menunjukkan rendahnya sikap kecemasan, lebih memiliki keterampilan sosial, dan meningkatkan self esteeem. Kelompok remaja yang bermain sepakbola dan bola basket menunjukkan sedikit perubahan pada personaliti dan penyimpangan, tetapi meningkat dalam hal self-esteem dan keterampilan sosial.

Sangat penting untuk dicatat bahwa berpartisipasi dalam kegiatan olahraga tidak cukup secara positif mempengaruhi perilaku negatif. Program olahraga harus dipersatukan dengan pengajaran secara sosiologis dan psikologis dalam upaya mendapatkan tujuan-tujuan yang diinginkan.

\section{PENDEKATAN DALAM PENGEM- BANGAN KARAKTER DAN NILAI- NILAI OLAHRAGA}

Meskipun banyak orang berbeda pandangan tentangbagaimana mengembangkan karakter dan nilai-nilai olahraga, tetapi paling tidak ada tiga pendekatan yang sering digunakan untuk dapat menjelaskannya, yaitu: pendekatan belajar sosial (social learning), pengembangan struktural, dan pendekatan sosial psikologikal (Gould, 2003: 528).

\section{Pendekatan Belajar Sosial (Social Learn-} ing Approach)

Perilaku agresi dan pengembangan karakter berkaitan satu sama lain, dan dapat dijelaskan melalui teori yang sama. Berdasarkan pendekatan belajar sosial, seperti yang dikemukakan oleh Albert Bandura (1977), sikap dan perilaku olahragawan sejati dipelajari melalui pemodelan atau belajar observasional, penguatan, dan pembandingan sosial (lihat Gambar 1). Pendekatan ini menunjukkan bahwa riwayat belajar sosial seseorang menentukan tingkatan olahragawan-nya.

Komponen Komponen Teori Belajar Sosial

Pemodelan atau Belajar Observasional (Belajar melalui apa yang dilakukan dan tidak dilakukan orang lain)

Penguatan (Reinforcement)

(Pemberian penguatan atau hukuman atas tindakan yang dilakukan)

Pembandingan Sosial

(Menunjukkan perilaku sesuai dengan perilaku temannya atau pembandingan kelompok)

\section{Gambar 1. Komponen Komponen Teori Belajar Sosial}

Sebagai contoh, melalui pengamatan, seorang siswa akan terhormat ketika melaporkan jumlah capaian skor sit-up kepada instruktur. Ahmad seorang siswa yang sedang belajar pendidikan jasmani berlatih sit-up dan kebugaran jasmani. Ahmad mengingingkan perhatian dan penilaian positif dari guru pendidikan jasmaninya. Perilaku Ahmad dilihat oleh teman-teman sekelasnya, 
dan semua siswa menginginkan hal yang sama mendapat penilaian dan perhatian positif dari gurunya. Guru pendidikan jasmani mencatat semua hal baikyang dilakukan para muridnya dan menguatkan dan menghargai segala perbuatan positif yang dilakukan para muridnya tersebut. Lingkungan belajar seperti inilah akan dapat membangun karakter.

\section{Pendekatan Perkembangan-Struktural (Structural-Development Approach)}

Weiss \& Bredemeier (Gould, 2003: 529) mengatakan bahwa berbeda dengan pendekatan belajar sosial, yang menekankan pada pemodelan, penguatan, dan pembandingan sosial, pendekatan perkembangan struktural menekankan pada bagaimana perubahan secara psikologikal dan perkembangan ketika siswa berinteraksi dengan pengalamanlingkungan untuk membentuk alasan-moral (moral reasoning). Dalam hubungan ini, para ahli psikologi olahraga mengajukan beberapa istilah yang tercakup dalam pendekatan perkembangan struktural ini, yaitu perkembangan moral (moral development), alasan-moral (moral reasoning), dan perilaku moral(moral behavior). Perlu dicatat bahwa moral yang dimaksud disini adalah moral yang tidak ada implikasinya dengan nilai-nilai keagamaan.

Alasan-Moral adalah proses keputusan ketika seseorang menentukan mana yang benar atau mana yang salah dari suatu tindakan tertentu. Karena itu, alasan moral memfokuskan pada bagaimana keputusan seseorang memutuskan beberapa tindakan tertentu. Sebagai contoh, membantu pemain yang terkena cedera ketika sedang bermain sepakbola dengan cara menghentikan permainan dengan cara menendang bola ke luar lapangan secara sengaja apakah perbuatan benar atau salah. Dengan kata lain, dalam pembelajaran peserta didik perlu didorong untuk dapat menemukan alasan-alasan yang melandasi keputusan moral yang tujuannya untuk mengontrol tindakan. Hal ini diperlukan agar seseorang dapat benar-benar memahami keputusan moral yang diambilnya, dapat mengidentifikasi alasan yang baik yang harus diterima dan alasan yang tidak baik yang harus ditolak atau diubah. Peserta didik harus dapatmerumuskan perubahan yang perlu dilakukan. Alasan yang baik adalah yang memberikan kontribusi dalam mengatasi situasi yang problematik. Cara ini memungkinkan perkembangan intelektual, menumbuhkan kebebasan berpikir, serta dapat memadukan proses dan hasil pendidikan secara harmonis. Berkaitan dengan hal ini, Zuchdi (2008: 6) menjelaskan bahwa fungsi lembaga pendidikan adalah menciptakan setting sosial yang memungkinkan implementasi pengetahuan untuk memecahkan masalah yang ada dalam masyarakat, selanjutnya yang terpenting adalah memberi kesempatan kepada peserta didik untuk mempelajari dan berlatih menentukan pilihan moral yang begitu beragam di Indonesia.

Perkembangan Moral adalah proses pengalaman dan pertumbuhan melalui kapasitas perkembangan seseorang untuk memberikan alasan bermoral. Sebagai contoh, dalam perencanaan pengajaran pendidikan jasmani, guru pendidikan jasmani mengharapkan para 
siswanya mendapatkan pengalaman dan perubahan perkembangan kognitif sehingga siswa mampu menentukan tindakan yang benar dan yang salah. Konsepsi moralitas perlu diintegrasikan dengan pengalaman dalam kehidupan sosial. Pemikiran moral dapat dikembangkan antara lain dengan dilema moral, yang menuntut kemampuan peserta didik untuk mengambil keputusan dalam kondisi yang sangat dilematis. Dengan cara ini, pemikiran moral dapat berkembang dari tingkat yang paling rendah yang berorientasi pada kepatuhan pada otoritas karena takut akan hukuman fisik, ke tingkat-tingkat yang lebih tinggi, yaitu berorientasi pada pemenuhan keinginan pribadi, loyalitas pada kelompok, pelaksanaan tugas dalam masyarakat sesuai dengan peraturan atau hukum, sampai yang paling tinggi, yaitu mendukung kebenaran atau nilainilai hakiki, khususnya mengenai kejujuran, keadilan, penghargaan atas hak asasi manusia, dna kepedulian sosial.

Perilaku Moral adalah tindakan perilaku yang terjadi benar atau salah. Dengan demikian, alasan-moral hasil dari pengalaman individual, dan perkembangan serta pertumbuhan siswa dan psikologikal yang memandu perilaku moral. Lebih lanjut, alasan moral adalah sekumpulan rentetan prinsip umum etika yang mendasari tindakan khusus secara situasional. Para pengembangan struktural menekankan bahwa kemampuan untuk memberikan alasan secara bermoral bergantung pada tingkatan kognitif dan perkembangan mental orang yang bersangkutan (misal, kemampuan anak untuk berpikir secara konkret atau abstrak). Alasan dan pe- rilaku moral bergantung pada tingkatan perkembangan kognitif individu itu (Gould, 2003:530). Zuchdi (2008:7) menjelaskan bahwa tindakan moral (perilaku moral) yang selaras dengan pemikiran moral (perkembangan kognitif) hanya mungkin dicapai lewat pencerdasan emosional dan spiritual serta pembiasaan. Sebagai contoh, seseorang yang mengerti bahwa budaya potong kompas dalam mencapai prestasi adalah tindakan yang tidak terpuji, tetap saja melakukan tindakan tercela tersebut apabila tidak sensitif terhadap penderitaan oranglain akibat tindakannya dan lemah iman.

\section{Pendekatan Sosial Psikologikal (Social Psychological Approach)}

Vallerand, dkk. (1997) dalam Gould (2003:531) menawarkan pendekatan ketiga untuk mempelajari moralitas dalam aktivitas jasmani. Vallerand Secara khusus menyarankan menggunakan pendekatan sosial-psikologikal yang lebih luas. Maksudnya, melihat moralitas dan karakter yang melekat pada diri seseorang dalam pendekatan perkembangan-struktural (misalnya, tingkatan perkembangan moral seseorang) ditambah rentang keluasan faktor-faktor sosial (misal, tipe orang, tingkatan olahraga kompetetif, sering terjadi perilaku tidak sportif di olahraga, belum lagi kepentingan/pressure yang lebih luas dan tidak selalu legal) yang sejalan dengan pemodelan, penguatan, dan pembandingan sosial dalam pendekatan belajar sosial. Hal penting yang perlu diperhatikan adalah bahwa agen-agen sosial (seperti: orang tua dan guru, pelatih) memberikan pelabelan atau pendefinisian olahragawan 
sejati. Dengan demikian, Vallerand menyarankan untuk melihat karakter dari pandangan yang lebih kompleks, perspektif personal dan faktor-faktor situasional yang menentukan ciri-ciri olahragawan sejati. Perkembangan karakter berkembang dari keputusan seseorang tentang benar atau salah dari tindakan minat orang itu dengan keterlibatan minat mutual.

Karena itu, penting mempertimbangkan sikap, nilai-nilai, dan normanorma budaya dari kelompok atau individu tertentu, dan tahapan alasanmoral dalam upaya memahami bagaimana meningkatkan perkembangan karakter dan ciri-ciri olahragawan sejati. Ini berarti, nampaknya mengambil keuntungan dari apa yang telah dipelajari melalui pendekatan belajar sosial dan perkembanganstruktural, sehingga menjadi pendekatan sosial-psikologikal.

\section{STRATEGI MENINGKATKAN PE- NGEMBANGAN KARAKTER}

Pendekatan belajar sosial, pengembangan struktural, dan sosial-psikologikal telah memberikan landasan pemahaman ciri-ciri olahragawan sejati dan pengembangan karakter. Sembilan strategi telah dikembangkan dari ketiga pendekatan di atas. Berikut dijelaskan bagaimana ke-9 strategi itu dapat mengembangkan karakater.

- Rumuskan dan Tuangkan dengan Jelas Ciri-Ciri Olahragawan Sejati di dalam Program

Ketiadaan definisi universal olahragawan sejati dalam program pendidikan jasmani atau olahraga akan menyebabkan guru pendidikan jasmani dan olahraga tidak dapat merumuskan dengan jelas dan dapat diterima mana perilaku yang baik dan mana perilaku yang tidak baik. Namun, guru dapat merumuskan dengan jelas ciri-cirinya seperti dituangkan dalam Tabel 2, terutama perilaku-perilaku yang menandakan nilai-nilai olahraga.

- Perkuat dan Gugah Perilaku yang Mencirikan Olahragawan Sejati

Sangatlah penting untuk menggugah dan memperkuat perilaku-perilaku atau sikap yang telah dirumuskan dalam program ciri-ciri olahragawan sejati. Sebaliknya, berikan hukuman dan penekanan pada perilaku-perilaku yang tidak tepat. Penting untuk melakukan penguatan dan hukuman terhadap perilaku yang positif dan negati secara konsisten.

- Pemodelan Perilaku-perilaku Baik dan Tepat

Identifikasiperilaku yang diinginkan dan contohkan dalam pemodelan pada segala tindakan-tindakan yang dilakukan. Karena perilaku lebih berarti daripada hanya sekedar kata-kata verbal, maka penting dalam setiap kegiatan olahraga dan latihan memberikan atau menunjukkan melalui pemodelan dari ciri-ciri olahragawan sejati yang dimaksud. Sering kali didengar, mudah dikatakan tetapi sukar dilakukan. Tentu setiap orang mudah melakukan kesalahan. Karena itu, ketika seseorang melakukan kekeliruan perlu segera mengakui kesalahan itu dan meminta maaf atas kekeliruan yang dilakukan. 
Tabel 2. Program Ciri-ciri Olahragawan Sejati Olahraga Usia Dini

\begin{tabular}{|c|c|c|}
\hline Konsentrasi Perilaku & Perilaku Olahragawan Sejati & Perilaku Non-Olahragawan Sejati \\
\hline Perilaku terhadap & Mengajukan pertanyaan secara & - Menghina wasit \\
\hline Wasit dan Panitia & $\begin{array}{l}\text { baik, menugaskan kapten untuk } \\
\text { mengajukan pendapat. }\end{array}$ & $\begin{array}{l}\text { - Beradu pendapat terhadap } \\
\text { panitia }\end{array}$ \\
\hline $\begin{array}{l}\text { Perilaku terhadap } \\
\text { lawan bertanding }\end{array}$ & $\begin{array}{l}\text { Memperlakukan lawan secara } \\
\text { penuh respek dan layak. }\end{array}$ & $\begin{array}{l}\text { - Melakukan perbuatan } \\
\text { sarkastik terhadap lawan } \\
\text { - Melakukan perilaku agresi } \\
\text { terhadap lawan }\end{array}$ \\
\hline $\begin{array}{l}\text { Perilaku terhadap } \\
\text { teman satu regu }\end{array}$ & $\begin{array}{l}\text { Hanya memberikan kritik } \\
\text { konstruktif dan gugahan positif }\end{array}$ & $\begin{array}{l}\text { - Membuat komentar negatif } \\
\text { Menghina teman }\end{array}$ \\
\hline $\begin{array}{l}\text { Perilaku terhadap } \\
\text { penonton }\end{array}$ & $\begin{array}{l}\text { Hanya membuat komentar } \\
\text { positif terhadap penonton }\end{array}$ & $\begin{array}{l}\text { - Beradu pendapat terhadap } \\
\text { penonton mengejek penonton }\end{array}$ \\
\hline $\begin{array}{l}\text { Aturan dan peratur- } \\
\text { an yang disepakati }\end{array}$ & $\begin{array}{l}\text { Mengikuti aturan dari Badan } \\
\text { Liga Keolahragaan }\end{array}$ & $\begin{array}{l}\text { - Mengambil keuntungan dari } \\
\text { aturan yang diberlakukan. }\end{array}$ \\
\hline
\end{tabular}

- Menjelaskan Mengapa Perilaku tertentu Baik dan Dapat Diterima

Hanya jika orang telah terinternalisasi prinsip panduan moral dapat menentukan salah atau benar sehingga dapat secara konsisten berperilaku baik dalam berbagai situasi dan kondisi. Karena itu penting, untukmemasukkan secara rasional berbagai komponen olahragawan sejati. Menurut Weiss (Gould, 2003:536), rasionalmemberikan penjelasan yang didasarkan pada elemen dasar tingkat alasan-moral, seperti: altruisme dan keseimbangan moral yang didasarkan pada kesepakatan mutualisme. Sangat penting untuk senantiasa memberikan rasionalisasi semua tindakan secara reguler kepada para peserta. Sebagai contoh, jika beberapa siswa merasa kurang terampil melakukan permainan dalam kegiatan pendidikan jasmani dan olahraga, maka yakinkan bahwa secara inklusi atas ketidakmampuan itu dalam beberapa alasan sebelum dilakukan keputusan (misalnya: penting untuk mengetahui semua alasan di balik suatu tampilan tugas gerak yang di- lakukan siswa). Berikan penjelasan secara rasional atas semua tindakan benar atau salah para siswa.

Menurut Marten (Gould, 2003: 536), sangat penting menekankan alasan di balik suatu tindakan. Kemampuan untuk menjustifikasi mulai berkembang pada usia 7 atau 8 tahun. Pada anak usia 10 tahun dapat ditekankan pada pengambilan peran. Kemudian, pada tingkatan empati tertinggi, kemampuan dua orang anak untuk melakukan perspektif satu sama lain bisa dilakukan ketika memutuskan bagaimana melakukan suatu tindakan.

- Diskusikan Dilema Moral dan Pilihan-pilihan

Untuk terjadinya efektivitas pendidikan moral, partisipan harus terlibat dalam dialog-diri dan diskusi kelompok tentang dilema moral dan pilihan-pilihan. Suatu dilema moral membutuhkan partisipan untuk memutuskan apakah suatu tindakan moral benar atau salah. Diskusi dapat berlangsung dalam berbagai cara pandang yang mungkin atau 
tidak mungkin bertentangan dengan aturan.

- Membangun Dilema Moral dan Pilihan-pilihan ke dalam Situasi Praktik

Setelah beberapa pemain mencoba memecahkan dilema, ikuti dengan diskusi tentang alasan moral yang melandasinya. Strategi ini untuk meningkatkan pengembangan karakter dan ciriciri olahragawan sejati membutuhkan waktu, perencanaan, dan usaha. Untuk suatu pengaruh optimal, para siswa harus mengulanginya secara konsisten sepanjang waktu, tidak hanya satu atau dua kali ketika para siswa dihadapkan pada suatu masalah.

- Mengajarkan Strategi Belajar Kooperatif

Meskipun kompetisi dan kooperatif penting untuk pengembangan optimal motivasi berprestasi. Anak-anak di Amerika Serikat lebih cenderung menyukai sifat kompetisi daripada kooperatif. Oleh karena itu, dalam pengajaran aktivitas jasmani para siswa harus dibelajarkan melalui strategi belajar kooperatif. Miller dkk. (Gould, 2003:538) juga menyebutkan bahwa kemampuan untuk belajar secara kooperatif penting dalam pengembangan karakter. Cara belajar kooperatif ini mungkin melibatkan penggunaan tingkatan tujuan dalam suatu permainan.

- Menciptakan Suasana Motivasional Berorientasi Tugas Gerak.

Penciptaan suasana motivasional berorientasi pada tugas gerak memaksa partisipan terfokus pada tugas daripada egonya sendiri sehingga dapat menjus- tifikasi kemampuan dirinya sendiri atas dasar penampilannya daripada melalui peningkatan pembandingan secara sosial. Sangat mudah mengajarkan ciri-ciri olahragawan sejati dalam kompetisi hanya saja perlu ditekankan ulang dan belajar terus menerus. Namun demikian, ini bukan berarti bahwa karakter tidak dapat dikembangkan melalui suasana kompetetif, hanya jika keuntungan untuk menirukan upaya pengembangan kearah pengembangan karakter dalam suatu susana motivasional berorientasi pada tugas gerak. Ketika seorang pemain mengembangkan karakter yang baik, kompetisi kemungkinan justru menjadiujian pertama apakah dia mampumempertahankan dan mengembangkan nilai-nilai yang diyakininya itu.

- Pemindahan Power (Kekuatan) dari Pemimpin ke Partisipan

Menurut Hellison dan Templin (Gould, 2003:538), pengembangan karakter dapat dipicu dengan baik pada lingkungan yang secara progresif memindahkan power (kekuatan) dari seorang pemimpin (Kapten) ke bawahan (partisipan/pemain) Sebagai contoh, seperti telah dikembangkan oleh Hellison bagaimana mengajarkan sikap tanggungjawab melalui pendidikan jasmani dan olahraga. Pertama, secara realistik pengajaran diawali dari sikap tidak bertanggungjawab, membantu mereka untuk dapat mengendalikan diri, pengendalian diri ini dikembangkan melalui tahapan keterlibatan mereka, pengerahan diri, dan akhirnya didapatkan sikap kepedulian untuk bertanggungjawab atas segala tindakan yang dilakukannya. 
PANDUAN PRAKTIS DALAM PENGEMBANGAN KARAKTER

Untuk memandu guru pendidikan jasmani dalam mengembangkan karakter siswa melalui aktivitas jasmani dan olahraga, beberapa isu filosofis perlu dikenali dalam ruang wawasan luas, termasuk peran guru pendidikan jasmani dan pelatih dalam pengembangan moral. Selain itu, guru pendidikan jasmani juga perlu memperhatikan peran kemenangan dan cara perilaku moral dibelajarkan atau ditransferkan kepada siswa di lapangan. Selain itu, kenali pula sisi ketidak sempurnaan alamiah pengembangan karakter.

\section{Peran Pendidik dalam Pengembangan Karakter}

Banyak orang meyakini guru dan pelatih tidak memiliki tanggungjawab pengajaran moral dan nilai-nilai kepada anak-anak remaja. Karakter dan moral adalah tanggungjawab orang tua dan tokoh keagamaan, mereka menentangnya, itu bukan tanggungjawab sekolah, terutama sekolah umum pemerintah. Tentu, dapat disetujui bahwa pengajaran moral bukan percampuran nilai-nilai keagamaan dengan tanggungjawab sekolah. Namun demikian, menelantarkan pendidikan karakter dalam nilainilai dasar seperti, kejujuran, empati, dan kepedulian sosial adalah suatu kesalahan besar. Guru pendidikan jasmani, pelatih, dan instruktur olahraga masyarakat justru mengajarkan nilai-nilai itu semua, baik secara sengaja atau tidak sengaja. Shields \& Bredemeier (Gould, 2003:539) menyatakan "bukan hanya sekedar bagaimana memenangkan kompetisi olahraga, olahraga ada- lah peluang untuk mengembangkan, membelajarkan, memindahkan, dan menanamkan nilai-nilai moral". Sebagai contoh, pelatih merekomendasikan apakah perlu beradu pendapat dengan wasit atau panitia; guru pendidikan jasmani apakah perlu mengajarkan dengan cara kompetetif atau kooperatif; seorang pelatih perlukan melatih atlet ketika sedang cedera. Keputusan yang perlu dibuat seringkali mempengaruhi sikap yang harus diperlihatkan, karena itu penting untuk mengetahui secara filosofis atas isu-isu yang dikemukakan di atas. Sangatlah terpuji mengenali nilai-nilai moral yang perlu diajarkan daripada mempengaruhi nilai-nilai orang lain secara paksa.

\section{Mengurangi Resiko dengan Cara Me- micu Kesuksesan}

Meskipun strategi guru pendidikan jasmani dan pelatih dapat menggunakan pengajaran karakter dan ciri-ciri olahragawan sejati, tetapi tetap perlu disadari bahwa banyak anak-anak remaja hidup di lingkungan yang memaksa mereka hidup dan berperilaku negatif (misalnya, penyalahgunaan narkoba, kehamilan pra-nikah, dan aktivitas "gang"). Lebih lanjut, nampaknya para ahli aktivitas jasmani dapat mengeliminir faktor-faktor resiko seperti di atas sebagai dampaklemahnya pengawasan danbimbingan dari para orang tua dan model peran yang tidak semestinya. Menurut Martinek \& Hellison (Gould, 2003:539), melalui aktivitas jasmani secara psikologikal,memulihkan kemampuan untuk sukses setelah mengalami tekanan mental atau stress dalam kehidupan. Berikan pengalaman berhasil pada siswa 
atau atlet. Sebuah kesusksesan atau kemenangan memiliki dua sisi baik dan buruk.

Kemenangan memainkan peran penting dalam pengembangan karakter. Pada satu sisi, penekanan terhadap kemenangan menimbulkan seseorang berani berbuat curang, melanggar aturan, dan berperilaku seolah-olah seperti yang terjadi di luar lapangan. Sisi lain, ketika para pemain mampu bertahan dengan nilai-nilai luhur dan mulia serta berpegang teguh pada pengembangan integritas, pembelajaran moral menjadi semakin bermakna. Kemenangan itu sendiri berada pada sisi netral dalam pengembangan karakter. Kunci penting adalah menempatkan kemenangan pada porsi yang semestinya.

Lebih lanjut, kemampuan ini berkaitan dengan kompetensi sosial, otonomi, dan optimisme dan harapan. Kompetensi sosial adalah kemampuan untuk berinteraksi secara sosial dengan orang lain dan menciptakan jejaring dukungan sosial secara kuat. Kelenturan dan empati nampaknya kritis dalam pengembangan atribut seperti ini. Menjadi sangat penting ketika belajar bagaimana bernegoisasi, berhadapan, dan menangani tantangan dari orang lain. Otonomi, kemampuan untuk bisa sukses dari kesusahan yang dialami memerlukan rasa pengendalian diri terhadap lingkungan sekitar dan merasakan serta bentindak secara independen. Dengan kata lain, anak-anak remaja merasakan otonomi, mereka dapat berfungsi sebagai individu menurut caranya sendiri. Optimisme dan harapan, Martinek dan Hellison (Gould, 2003:539) menyatakan bahwa salah satu cara terbaik dalam meningkatkan meraih kesuksesan di kalangan kaum muda adalah melalui pengembangan program aktivitas jasmani.

\section{Pemindahan Nilai-nilai pada Ling- kungan Non-Olahraga}

Sangatlah mustahil belajar nilainilai di lapangan atau di tempat gymnasium terjadi pemindahan nilai-nilai dengan sendirinya. Transfer nilai hanya dapat terjadi ketika pembelajaran nilainilai itu terjadi secara disengaja. Jika seorang guru pendidikan jasmani dan olahraga ingin mengajarkan nilai-nilai melalui aktivitas jasmani atau olahraga, guru tersebut harus mampu mendiskusikan bagaimana nilai-nilai itu dapat ditransfer ke dalam lingkungan nonolahraga. Sebagai contoh, ketika seorang guru ingin mengajarkan siswanya sikap kerjasama dalam permainan terbawa dalam kehidupan sehari-hari mereka di luar situasi non-olahraga, maka perlu didiskusikan bersama siswa nilai kerjasama itu dalam konteks yang lebih bermakna (misalnya: bekerjasama dalam program sekolah). Dengan demikian, inilah satu bukti keuntungan pendekatan pengembangan-struktural.

Prinsip belajar sosial yang meningkatkan sikap dan perilaku olahragawan sejati cenderung memerlukan situasi khusus. Seperti, mengajarkan siswa untuk berlaku jujur di lapangan tidak akan terbawa dalam pembelajaran matematik. Namun demikian, jika guru ingin menekankan alasan moral, perilaku siswa cenderung akan berpengaruh saling silang di antara satu dengan matapelajaran lain. Dengan demikian, perlu seorang guru pendidikan jasmani, 
ketika akan mengajarkan nilai-nilai melalui aktivitas jasmani dan olahraga, diskusikan dan pelajari bagaimana nilainilai ini ditransfer ke dalam situasi lingkungan non-olahraga.

\section{Miliki Harapan Realistik}

Peningkatan karakter dan ciri-ciri olahragawan sejati melalui aktivitas jasmani dan olahraga bukanlah suatu proses yang sempurna. Guru pendidikan jasmani tidak bisa mengajarkan kepada semua siswa pada saat yang sama. Perlu dipahami keberhasilan seseorang pasti disertai dengan kegagalan orang lain. Ketidaksempurnaan pengembangan karakter ini tetap memberikan secercah harapan optimistik meskipun mensituasikan beberapa pengalaman masa lalu.

\section{PENUTUP}

Karakter dan nilai-nilai moral yang diyakini terkandung dalam aktivitas jasmani dan olahraga tidak dengan sendirinya terinternalisasi dan terproyeksi dalam kehidupan sehari-hari dari pelaku atau partisipan aktivitas jasmani dan olahraga tersebut, melainkan nilai moral yang telah dipilih harus diorganisasikan, dikontruksi, dan ditransformasikan ke dalam struktur dasar penalaran individu yang berpartisipasi di dalamnya.

Menyadari begitu pentingnya penguatan karakter nilai-nilai moral pada anak-anak sejak dini, maka sebagai guru penjas, pelatih klub olahraga selalu memperhatikan strategi pembelajaran dan pelatihan yang dapat mentransformasikan nilai-nilai moral sebagai wujud tanggung jawab profesi.

\section{UCAPAN TERIMA KASIH}

Pada kesempatan ini, penulis mengucapkan banyak terima kasih kepada Redaktur dan segenap pengurus Jurnal Cakrawala Pendidikan yang telah memberikan mimbar bagi komunikasi ilmiah ini.

\section{DAFTAR PUSTAKA}

Auweele, Y.V. et. al. 1999. Psychology for Physical Educators. Champaign, Illinois: Human Kinetics.

Gould, Daniel and Weinberg, Robert S. 2002. Foundation of Sport and Exercise Phsychology, 3nd Edition. Champaigh, IL: Human Kinetics.

Maksum, A. 2005. “Olahraga Membentuk Karakter: Fakta atau Mitos". Jurnal Ordik. Edisi April Vol. 3, No. 1/2005.

Maksum, A. 2007. Psikologi Olahraga: Teori dan Aplikasi. Surabaya: Fakultas Ilmu Keolahragaan - Universitas Negeri Surabaya.

Martinek. 2009. “Fostering Character Education through Value-Based Physical Ativities". Makalah Disampaikan pada Semiloka di SMA N 6 Jakarta Mei 2009.

Shields, D L L. \& Bredemeier, B J L. 1995. Character Development and Physical Activity. Champaign, IL: Human Kinetics.

Shields, D L L. \& Bredemeier, B J L. 2006. "Sport and Character Deve- 
lopment". Research digest, Series 7, No. 1, March 2006.

Stornes, T., \& Ommundsen, Y. 2004. "Achievement Goals, Motivational Climate and Sportspersonship: A Study of Young Handball Players". Scandinavian Journal of Educational Research, 48, 205-221.
United Nation. 2003. Sport for Development and Peace: Towards Achieving the Millenium Development Goals. Report from the United Nations Inter-Agency Task Force on Sport for Development and Peace.

Zuchdi, Darmiyati. 2008. Humanisasi Pendidikan. Jakarta: Bumi Aksara.

Stuntz, C. P. \& Weiss, M. R. 2003. “Influence of Social Goal Orientations and Peers on Unsportsmanlike Play". Research Quarterly for Exercise and Sport, 74, 421-435. 